HUBERT STYS

Instytut Stosunków Międzynarodowych UMK

\title{
Milovan Đilas o wodzach rewolucji
}

ilovan Đilas (1911-1995) to już raczej zapomniana postać europejskiej lewicy XX wieku, a w Polsce zdecydowanie zbyt rzadko prezentowana. Po raz pierwszy o Czarnogórcu świat usłyszał w czasie II wojny światowej, kiedy to jako jeden z liderów jugosłowiańskiej komunistycznej partyzantki wszedł do ścisłego kierownictwa ludowej Jugosławii. Po 1948 roku był jednym z najbardziej zażartych krytyków Związku Radzieckiego i autorem teoretycznych tekstów, kładących podwaliny pod powstającą ideologię titoizmu. Podążając w kierunku modyfikacji komunizmu, Đilas odszedł w pewnym momencie za daleko - w 1954 roku Tito zdecydował się usunąć go z KC i najwyższych funkcji państwowych, a później dwukrotnie zamykał W więzieniu (na ponad 8 lat). W 1957 roku Milovan Đilas zdobył światowe uznanie publikując Nowa klasę, a w 1962 r. - Rozmowy ze Stalinem. Jako niezwykle cenne historycy traktują jego cztery tomy wspomnień, a szczególnie te odnoszące się do jego doświadczeń z okresu sprawowania władzy i czasu wojny domowej (1941-1945).

W latach 60. Đilas definitywnie rozszedł się z marksizmem, uznawał siebie za socjaldemokratę. Po 25 latach „komunizowania”, osiągnięciu szerokiej wiedzy teoretycznej, jak i poznaniu praktycznych możliwości marksizmu, były szef agitpropu zaczął pisać wiele artykułów o naturze komunizmu. Coraz więcej refleksji nachodziło go szczególnie po XX Zjeździe KPZR, po wydarzeniach węgierskich, czechosłowackich i polskich. Teksty te drukował tylko i wyłącznie poza granicami Jugosławii, gdyż Tito i jego dwór postanowili raz na zawsze skreślić Đilasa z życia politycznego, a nawet publicystycznego czy literackiego Jugosławii. Jednocześnie, poprzez takie działania, tworzyli mit „opozycjonisty nr 1”, który na Zachodzie uzyskał ogromną publicz- 
ność, a senator Edward Kennedy w 1968 roku w Waszyngtonie wręczał mu „Nagrodę Wolności”.

W niniejszym szkicu zaprezentowane będą najważniejsze wnioski Đilasa dotyczące „wodzów rewolucji” (formułę tę potraktujemy w znaczeniu ogólnym), jedne mniej, inne bardziej oryginalne, które autor przedstawiał szerszej publiczności od lat 60. do końca 80. Przypomnimy jego poglądy dotyczące Marksa, Lenina, Stalina, Tity i Gorbaczowa. Cechą charakterystyczną działalności pisarskiej i publicystycznej Đilasa jest barwne odmalowywanie biografii ludzi, z którymi miał okazję obcować, lub postaci historycznych jak Marks - którego dzieła wnikliwie studiował. Co oczywiste, najlepsze obrazy Đilasa to sylwetki liderów komunistycznych. Pisanie o nich było dla niego o tyle łatwe, że sam przez lata był komunistą. Oceniał, że niezależnie od przynależności ideologicznej, wodzów (liderów narodowych) charakteryzuje jedna rzecz: są motywowani chęcią zrobienia czegoś wielkiego dla swojego narodu lub człowieczeństwa - przede wszystkim - aby zmienić tok historii. W komunizmie i faszyzmie zdecydowanie trudniej jest zostać wodzem niż w państwie demokratycznym, oceniał Đilas. W demokracji bowiem przywództwo trzeba w dużej mierze wywalczyć talentem i zdolnościami, obiecaniem zmian na lepsze. W komunizmie natomiast trzeba robić mniej więcej to samo, ale z tą różnicą, że dodatkowo trzeba pokonać całą grupę twardych ideologicznych strażników systemu i jego formalnej - ustrojowej tradycji ${ }^{1}$.

\section{W okowach komunizmu}

Milovan Đilas zaangażował się w działalność polityczną w chwili, kiedy następowało stalinizowywanie europejskich partii komunistycznych, co w przypadku Jugosławii utożsamiał Josip Broz-Tito. W 1938 roku kierownictwo KPJ zostało złożone $\mathrm{z}$ wiernych wykonawców poleceń płynących z Moskwy. W tym czasie ideologów i liderów komunizmu Đilas traktował jak bogów, był w pełni oddany ideologii i zupełnie bezkrytyczny dla mających miejsce wydarzeń.

W czasie wojny domowej 1941-1945 Đilas jako szef agitpropu za jedną ze swoich podstawowych lektur uważał Historię WKP(b), w okresie komunistycznej „Republiki Užickiej” drukował jej egzemplarze w tysiącach sztuk, które potem w pośpiechu wywoził ciężarówką, jak skarb, z odbijanego przez Niemców obszaru. W 1942 roku pozwolił sobie napisać: „Stalin jest najbardziej zaciekłym przeciwnikiem wszystkiego nieludzkiego, to najtroskliwszy i najmądrzejszy wychowawca ludzkiej szlachetności. (...) Związek Radziecki to jedyne państwo bez tajnych zamierzeń. On nie tylko nie chce podporząd-

1 M. Đilas, O vođima, w: tenże, Pad nove klase, Beograd 1994, s. 220. 
kować sobie inne narody, ale chce dać pomoc tym zniewolonym i ich walce wyzwoleńczej przeciwko hitlerowskiej tyranii. (...) Stalin - to epoka, najbardziej decydująca w historii człowieczeństwa. Stalin - to Lenin dnia dzisiejszego"2. W 1943 roku napisze artykuł pod tytułem Armia Czerwona - wyzwoliciel człowieczeństwa. Sam po latach przyznawał, że jego stosunek do Stalina był podobny do wiary religijnej ${ }^{3}$.

Związek Radziecki stanowił dla niego ideał, wzór do osiągnięcia. Wizyta Đilasa w Moskwie wiosną 1944 roku była pierwszą konfrontacją z mitem, w październiku 1944 r. poznał z kolei moralność żołnierzy Armii Czerwonej, którzy uczestniczyli w wyzwalaniu Belgradu. Jego krytyczne uwagi spowodowały niechęć Moskwy do jego osoby: w okresie do 1946 roku złośliwe uwagi Stalina o Đilasie, których generalissimus nie omieszkał wielokrotnie powtarzać, ciążyły nad Đilasem jak zmora. Nie mógł przeboleć, że wielki Stalin, który był twórcą nowoczesnego państwa radzieckiego i zwycięzcą w ostatniej wojnie, tak nim gardzi ${ }^{4}$.

Wielkie zmiany nastąpiły po 1948 roku i po pamiętnej rezolucji Kominformu z czerwca 1948 roku. Đilas po krótkim wahaniu stanął po stronie swojego sekretarza generalnego - Tity, i swoje zdolności polemiczne rzucił do walki z wypaczeniami stalinizmu. Szczególnie od 1950 roku udział Đilasa w wojnie ideologicznej z ZSRR był niezwykle cenny. Utworzył teorię o państwowym kapitalizmie, który w jego mniemaniu powstał w ZSRR, oraz o przerodzeniu się warstwy rządzącej w biurokrację, która powstrzymała tam rozwój socjalizmu. Đilas - jako jeden z pierwszych Jugosłowian - oficjalnie i imiennie wskazał na Stalina, że nie ma on racji w sporze (już jesienią 1948 r.). Z biegiem lat krytyka Stalina i jego działań przybierała coraz większe rozmiary, jednocześnie wracano do założycieli marksizmu, nie spaczonych stalinizmem, jako źródła prawdziwej, nieskażonej ideologii. Stalina Đilas nazywał wybitnym teoretykiem, ale już tylko procesu coraz większego panowania uprzywilejowanej biurokracji w ZSRR. Jego dwa ostatnie artykuły (o językoznawstwie i problemach ekonomicznych w ZSRR) oceniał jako „głupie, nienaukowe, płytkie i dziecinne teorie tak, że człowiek musi zapytać, jak w tym wielkim kraju (...) doszło do takiego zawężenia ludzkiej i naukowej myśli, że sam Stalin zmuszony jest do odgórnego potwierdzania takich prawd jak ta, że język jest środkiem komunikacji między ludźmi (...)"5. Stwierdzał ze smutkiem, że taka postać jak Stalin zadała wielkie szkody ruchowi robotniczemu i sprawie socjalizmu.

\section{M. Đilas, Staljin, „Borba”, 7 XI 1942 r.}

Chrystus $i$ komisarz, w: Stalin i stalinizm, rozmowy George'a Urbana, Londyn 1987, s. 188.

O swoich trzech wizytach w Moskwie pisze obszernie w Rozmowach ze Stalinem.

M. Đilas, Da li se Staljin vrti u krugu?, w: Tenże, Pad nove klase..., s. 125. 
Ten etap w życiu Đilasa wspominamy tu po to, by pokazać, jak jego oceny dotyczące wodzów rewolucji zmieniały się w zależności od zadań propagandowych jego rodzimej partii komunistycznej. Dopiero po zerwaniu więzi z komunizmem oceniał ich już bardziej otwarcie i obiektywnie. Na przykładzie Stalina widać, jak Đilas przeszedł od uwielbienia do wrogości, by potem (zupełnie przypadkowo i nieświadomie) w sposób dialektyczny zsyntetyzować swoje oceny i przedstawić je opinii publicznej.

\section{Marks}

Jako były lider partyjny, znający doskonale tematykę budowy społeczeństwa komunistycznego, Đilas jednoznacznie stwierdzał, że idee Marksa są nie do zrealizowania. Niemniej, marksizm oceniał jako pierwszą światową ideologię, o ogromnym historycznym znaczeniu. Prace dżilasowego „genialnego Marksa” to wielka synteza największych filozofii XIX wieku: „to jedna z niewielu żywych istot, która streszcza sobą całą epokę"6. W osobie Marksa wyróżnił trzy najważniejsze komponenty: proroka, naukowca i pisarza. Marks to jeden z największych proroków: pierwszy prorok o znaczeniu światowym, gdyż tworzył już w epoce rozwiniętej komunikacji. W odróżnieniu od innych, całym swoim bytem wierzył w potęgę nauki i stosował naukową metodę. „Wszyscy XIX-wieczni prorocy, w odróżnieniu od Marksa, nie byli w stanie dojrzeć, że wszystkie narody, cała ziemska populacja, musi zmieniać i bez przerwy zmienia swój sposób życia, a tym samym relacje społeczne, przystosowując je do coraz bardziej doskonalącego się przemysłu"7.

Marks - naukowiec - to dla Đilasa przede wszystkim jeden z założycieli nowoczesnej socjologii, jako pierwszy zrozumiał, że społeczeństwo można poddawać badaniom, tak, jak inne zjawiska. Marks pisarz - to przede wszystkim wyjątkowy barokowy styl ${ }^{8}$, szerokość i żywotność skojarzeń i olimpijskie wyżyny poczucia humoru. Oczywiście niesamowite opisy biedy proletariatu, skąpstwa i bezduszności kapitalistów, analizy walk politycznych we Francji - to najbardziej wstrząsające dokumenty historii. $\mathrm{W}$ ten sposób żaden z uczniów Marksa nie może się mierzyć pięknem stylu, głębokością myśli, i przede wszystkim, jego wszechstronnością.

W koncepcji utworzenia idealnego państwa, według Đilasa, Marks zdecydowanie dystansuje Platona czy Arystotelesa, gdyż w swojej stymulowanej naukowym podejściem wizji był w stanie zarazić ideą miliony ludzi na całym

M. Djilas, The Unperfect Society, New York 1969, s. 43.

Tamże, s. 44.

Ten pogląd Đilas przyjął już w latach 30. Wówczas mawiano wśród komunistów, że Marks był barokowy, Lenin ognisty i mocny, a Stalin monumentalny. 
świecie. Inne filozoficzne pomysły na doskonałe społeczeństwo nigdy nie spotkały się z tak powszechną absorpcją.

Đilas wskazuje, że Marks poszukiwał w nauce wyjaśnienia swoich wierzeń, dlatego „był on najpierw komunistą, po czy stworzył komunistyczną doktrynę". Jego doktryna była otwarta na zmiany, niemniej po AntyDühringu Engelsa i zdogmatyzowaniu przez późniejszych uczniów, marksizm przestał akceptować nowe odkrycia w dziedzinie nauk ścisłych, natomiast stając się pełną teorią i ideologią, stracił aktualność.

Marksowi nie udało się zostać absolutnym wodzem swojego politycznego ruchu (I Międzynarodówki); w paryskiej komunie (pierwszej próbie wprowadzenia dyktatury proletariatu) zwolennicy Marksa grali role drugorzędne. Ale w nauce socjalizmu Marks nie miał sobie równych, stwierdza Đilas. Po śmierci został uznany za mesjasza, jako bezsporny prorok nieuniknionego „nowego szczęśliwego świata”. Poglądy Đilasa nie odbiegają od przyjętych w literaturze ocen Marksa. Wyjątkowe jest wysoko sytuowane przez Czarnogórca „proroctwo” niemieckiego myśliciela, jak i jego humanistyczne talenty.

\section{Lenin}

Według Đilasa, Lenin to, obok Bernsteina, największy teoretyk, który wzbogacił marksizm, w tym przypadku swoją teorią partii rewolucyjnej i praktyki rewolucyjnej. Nie jest to równoznaczne z postrzeganiem go jako teoretyka wybitnego. Jego dokonania są po prostu większe niż innych zwolenników i teoretyków marksizmu epoki, w której faktycznie niewielu było w stanie, pomimo wielkich starań, oryginalne rozwinąć ten nurt. Lenin doszedł jednakże do sprzeczności - stał się rewizjonistą Marksa - na podstawie jego nauki o rewolucji zbudował partię $\mathrm{z}$ ideologią, przeciwną humanistycznej nauce Marksa, odrzucając razem z tym idee demokratycznego socjalizmu i socjalnej demokracji. Lenin był bardziej dogmatyczny od F. Engelsa, jak oceniał Đilas, niemniej to bolszewik „miał zdecydowanie głębsze, prawie nieomylne wyczucie realiów epoki, jak i rewolucyjnych warunków dla Rosji" ${ }^{10}$. Lenin to geniusz rewolucji - dokonał syntezy utopijnych dogmatów i rewolucyjnej organizacji. Za jego teoretyczne dokonania Đilas uznawał przede wszystkim obronę marksistowskiego materializmu przed rewizjonistami, wyrażoną w Materializmie i emipokrytycyzmie. To dzieło uważał za najważniejsze filozoficzne dokonanie Lenina, choć samo w sobie nie było ono czymś oryginalnym, ledwie bezwarunkowym przyjęciem za swoje - poglą-

M. Djilas, The Unperfect..., s. 116.

10 Tamże, s. 105. 
dów Marksa. Zenkowski w swojej krytyce stwierdza, że Leninowi właściwe jest jednostronne podejście do filozofii historii, nadające jego pracy cech swoistej scholastyki (w jak najgorszym sensie tego słowa) ${ }^{11}$. Đilas doceniał leninowskie rozwinięcie teorii rewolucji, władzy i rewolucyjnej strategii oraz taktyki. Nie decydował się natomiast na krytyczną ocenę Lenina, szczególnie jego kluczowych „teoretycznych nonsensów” (określenie D. Wołkogonowa) o możliwości budowy socjalizmu w krajach stanowiących najsłabsze ogniwo kapitalizmu. Przecież to na Zachodzie baza materialna socjalizmu była już gotowa, a tu nagle stwierdzenie, że większe szanse na postęp ma zacofana Rosja $^{12}$. Inaczej leninizm postrzega R. Tucker, który widział w nim doktrynę wewnętrznie zróżnicowaną i twierdził, że „istnieje szereg różnych leninizmów"13.

Đilas poprzez pryzmat tej głównej postaci i jej cechy osobowościowe postrzegał istotę rewolucji październikowej. Lenin zbudował własną potęgę właśnie poprzez rewolucję, zaś nowe społeczeństwo ukształtował poprzez dogmaty. Nowa forma władzy była swego czasu możliwa w Rosji i nieugiętość Lenina pozwoliła stworzyć dogodne warunki do budowy nowego społeczeństwa. Nie zmienia to faktu, że jego obraz społeczeństwa i stosunków międzynarodowych nie był wierny realiom. Ponadto, według Marksa i konsekwentnie Lenina, państwo miało zacząć obumierać zaraz po swoim powstaniu. Ale rozwinęło się wbrew planom: po ustanowieniu przez partię monopolu władzy - nierzeczywista i niemożliwa do utworzenia dyktatura proletariatu stopniowo degenerowała się w stronę dyktatury partyjnej biuro$\mathrm{kracji}^{14}$. Dlatego Đilas nazywa Lenina inicjatorem nowej klasy. Nie było to jego życzeniem, nie miał tego w planach, ale faktycznie stworzył spójną koncepcję o jej posłannictwie i wyjątkowej roli w budowie nowego społeczeństwa $^{15}$. Lenin nie potrafił uciec z okowów swojej epoki i wyprzedzić ją. Nie zrozumiał, że partyjna biurokracja to zupełnie nowe zjawisko, nowa warstwa pasożytnicza. Jego krytyka biurokracji, według Đilasa, sprowadzała się do żądań o lepsze uczucia, o ducha przyjaźni wewnątrz partii i bardziej skuteczną administrację ${ }^{16}$. Pipes z kolei przypomina, że Lenin strasznie się denerwował postępującą biurokratyzacją, że pod koniec życia miał na tym punkcie obse-

W. Zenkowski, Istorija russkoj fiłozofii, t. 2, Paryż 1950, s. 285.

D. Wołkogonow, Lenin. Prorok raju, apostoł piekła, Warszawa 2006, s. 93.

Wielu Leninów?, w: Stalin i stalinizm..., s. 144.

Tamże, s. 228.

M. Dżilas, Nowa klasa wyzyskiwaczy, Paryż 1957, s. 57.

M. Djilas, Lenin, „The Times Saturday Review”, nr 57736, 6 XII 1969, s. 21. 
$\operatorname{sje}^{17}$. Poświadcza to jednakże tezę, że rozwój biurokracji Lenin co najmniej zignorował w swoich przemyśleniach.

Đilas przypominał, że Lenin nie był twórcą teorii o kapitalistycznym stadium imperializmu, lecz że przejął to od Hobsona. Leninowe schematyczne rewolucyjne wnioski o powstawaniu coraz mniejszej grupy właścicieli (monopole i trusty) nie brały pod uwagę zupełnie innych rozwiązań. Teoria ta należała do jego największych pomyłek - nigdy nie doszło w efekcie sprzeczności klasowych do połączenia ruchu wyzwoleńczego w koloniach $\mathrm{z}$ rewolucjami proletariackimi w metropoliach. Đilas w swojej krytyce nie pozwala sobie jednakże na stwierdzenia, jak D. Wołkogonow: o ciasnocie poglądów Lenina, o jego filozoficznych majaczeniach ${ }^{18}$. Do swojego bohatera podchodzi z wyjątkową wyrozumiałością.

Z biografii Lenina Đilas wyciągał wnioski ogólne, dotyczące wodzów narodowych czy ideologicznych. O wielkich zdolnościach „wodza rewolucji” świadczy to, że aby dojść do władzy musiał ideologicznie pokonać wielkie tuzy ruchu robotniczego (Plechanow, Martow). Musiał też dokonać rozłamu w ruchu socjaldemokratycznym i stworzyć partię nowego typu, która posłużyła jako instrument, nowej, totalnej władzy. Te jego działania i metody były idealne dla wprowadzenia systemu totalitarnego. Leninizm - wynaleziony i gruntowany przez jego następców - był specyficzną konstrukcją, pozwalająca trzymać władzę i rozwijać ekspansję totalitarnego komunizmu.

Tragedia Lenina ma naturę historyczną - wyciąga wnioski Đilas - jego dzieło przeobraziło się w swoje przeciwieństwo, a jego wierzenia w iluzje i złudzenia. System ten, skazany na historyczną porażkę, okazał się jednakże wyjątkowo żywotny. Wielka przepaść - oddzielająca od niego nowoczesny świat - i zmieniający się układ stosunków międzynarodowych, zmusiły go w końcu do kapitulacji.

\section{Stalin}

Đilas unikał rozpisywania się na temat morderczych, maniakalnych skłonności Stalina. Stwierdzał, że (przynajmniej na podstawie własnych z nim spotkań) nie może potwierdzić kryminalnej i opętanej złem natury Stalina - objaśnienia tych zachowań należy szukać raczej w idei i porządku państwowym. Ta idea budowania jakiegokolwiek w pełni bezklasowego społeczeństwa, pisał, w samym swoim sensie jest mitomańska i nieracjonalna, a porządek założony na bezprawiu sam z siebie przestępczy ${ }^{19}$. Konstatował,

R. Pipes, Rosja bolszewików, Warszawa 2005, s. 467.

1 D. Wołkogonow, Lenin..., s. 99, 329.

19 M. Đilas, O Staljinu - staljinova ličnost, w: Tenże, Pad nove klase..., s. 231. 
że wszelkie możliwe przestępstwa były dla Stalina wykonalne, łączył cechy wielu poprzedzających go w historii tyranów: Nerona, Kaliguli, Borgii, Iwana Groźnego, Robespierre'a, a nawet współczesnego mu Hitlera. Zakładał, że to Stalinowi przypadnie wątpliwa sława największego mordercy $\mathrm{w}$ historii ludzkości ${ }^{20}$.

Jednym z wątków, który Đilas bardzo często poruszał, była sprawa Stalina jako spadkobiercy Lenina. Wracał w swoich analizach do testamentu Lenina, odczytanego na XIII Zjeździe WKP(b). W dokumencie tym dostrzega to, co inni często przepuszczają - w charakterystyce Stalina nie ma ani słowa o jego politycznych niedomaganiach. Znajduje tylko złe cechy osobowościowe, nie ma to jednak wpływu na ideologiczny wizerunek późniejszego generalissimusa. Dlatego będzie twierdził, że Stalin, współbojownik Lenina, to również jego uczeń, mający największe sukcesy, najbardziej konsekwentny leninista. Wszystko, co Stalin zrobił - od łagrów do industrializacji i podporządkowania sobie narodów środkowoeuropejskich - zapoczątkował Lenin. Stalin nie zniszczył niczego, co zapoczątkował Lenin - oprócz starej kadry partyjnej, która przeszkadzała mu we wprowadzeniu tyranii i w kontynuacji dzieła poprzednika. Poglądy te - w czasie ich przedstawiania - były wyjątkowo niewygodne dla wielu ludzi związanych z europejską radykalną lewicą, komunistów poszukujących źródeł ideologii z pominięciem wypaczeń Stalina. Stalina uważano - i do dziś się uważa - za winnego odejścia od polityki leninowskiej, powstania mechanizmów administracyjnych sterujących totalitarnym państwem ${ }^{21}$. Robert Tucker stwierdzał, że stalinizm to „mało prawdopodobne" następstwo leninizmu. Z poglądami Đilasa zgodzili się jednakże i D. Wołkogonow, i R. Pipes. „Lenin nigdy nie wyrzekłby się dyktatury. Nadal istniałyby terror, kolektywizacja i polowania na "wrogów ludu»"22. Đilas zdecydowanie zakładał, że stalinizm de facto nie jest czymś odrębnym od leninizmu. Pojęcie stalinizmu może ewentualnie istnieć jako określenie totalnego terroru ${ }^{23}$, niemniej stanowi kontynuację dzieła rozpoczętego przez Lenina - budowy nowego porządku społecznego ${ }^{24}$.

Stalin to dla Đilasa wielki kodyfikator leninizmu, który w poglądach filozoficznych nie różnił się od Lenina. Chodzi mu tu przede wszystkim o używanie nauki marksizmu dla dokładnego przewidywania losów świata, społeczeństwa i człowieka ${ }^{25}$. W kodyfikacji całej nauki marksizmu i przedstawie-

Tenże, Staljinova senka nad naslednicima, w: Tenże, Pad nove klase..., s. 244.

Zob. np. poglądy J. Borisowa, w: Fenomen Stalina, Warszawa 1988, s. 58.

D. Wołkogonow, Lenin..., s. 468; Zob. również: R. Pipes, dz. cyt., s. 544.

Đilas stwierdzał, że Hitler jedynie mógł marzyć o tak totalnej władzy, jaką miał Stalin.

M. Đilas, Teze o Staljinu, w: Tenże, Pad nove klase..., s. 250.; Chrystus i komisarz..., s. 160.

M. Djilas, The Unperfect..., s. 71. 
niu jej w skondensowanej formie Stalin nie ma sobie równych, w tej kwestii przyznawał mu absolutne pierwszeństwo. Đilas odrzucał więc poglądy, że Podstawy leninizmu to dzieło słabej wartości, prymitywne pod względem stylu, a Stalin to ani teoretyk, ani pisarz (jak twierdzi z kolei B. Bażanow).

Đilas stawia również bardzo ważne pytanie: Czy Stalin wierzył w komunizm? Poszukując odpowiedzi doszedł do wniosku, że Stalin z pewnością uwierzył w możliwość budowy socjalizmu w jednym kraju. Wiedział, że jest tyranem, ale uważał, że do komunizmu można dojść tylko tyranią. W przyszłości, jego tyranię miało usprawiedliwić stworzenie nowego porządku społecznego - porządku marzeń ${ }^{26}$. Zarzuty o brutalność stalinizmu Đilas zawraca z ich ogólnoludzkiego wymiaru - to co osiągnięto w ZSRR ( i co chciano osiągnąć) było nie do zrealizowania w jakikolwiek inny, mniej brutalny sposób. Stalinowski komunizm - to z założenia wspólnota „doskonałych” ludzi: wspólnota robotów lub insektów. Wspólnota bez jednostek, bez rzeczywistych, mogących popełniać błędy osób.

Główna teoria Đilasa - powstanie „nowej klasy” w państwach komunistycznych wiąże się bezpośrednio z osobą Stalina. To właśnie za jego czasu wąska grupa byłych rewolucjonistów doszła do pełni władzy i przekształciła się w uprzywilejowaną warstwę społeczną. W dyskusji nad tym tematem Đilas stawił pytanie: czy „nowa klasa” była efektem działań Stalina, czy też zupełnie odwrotnie: czy to Stalin nie był produktem „nowej klasy”? W swojej książce jednoznacznie stwierdza, że grupie komunistycznych administratorów bardziej pasował Stalin, który zapewniał jej powolne uwłaszczanie się, możliwe przy koncepcji budowy socjalizmu w jednym kraju. Wprost przeciwnie do Trockiego - który zamierzał prowadzić rewolucję w dalszym ciągu na pozostałe obszary Europy. W konsekwencji Stalin został przez biurokrację poparty bezwarunkowo, co było źródłem jego mocy i co utworzyło jego niczym nieograniczoną tyranię. Stalin poprzez scentralizowaną, polityczną biurokrację kontynuował carski despotyzm. Bardzo rozpowszechnione są jednak poglądy, że to Stalin był twórcą machiny aparatu państwowego, prawdziwej piramidy władzy ${ }^{27}$. U Wołkogonowa pojawia się określenie: Stalin - mistrz aparatu, istny „profesor biurokracji” ${ }^{28}$.

Stalin, podobnie jak Lenin, by dojść do władzy, musiał pokonać przeciwników - strażników ideologii komunistycznej, w większości przypadków przerastających go intelektualnie. Ludzie ci górowali nad nim czy to swoją rolą w rewolucji, kulturą, mową, darem pisarskim (Trocki, Bucharin), czy

Tamże, s. 257.

Zob. przykładowo: A. de Jonge, Stalin and Shaping of the Soviet Union, London 1986, s. 305.

28 D. Wołkogonow, Stalin. Wirtuoz kłamstwa, dyktator myśli, Warszawa 2006, s. 750. 
świetną znajomością nauki Marksa i Lenina. Ponadto, mogli oni korzystać $\mathrm{z}$ „testamentu Lenina”, gdzie ten wypowiadał się przeciwko pozostawieniu Stalina jako sekretarza generalnego partii. Pomimo tylu przeciwności Stalin wyszedł z walki o władzę zwycięsko, co samo w sobie świadczy o jego wielkich możliwościach.

Stalin, twórca zamkniętego socjalistycznego systemu, był jego orężem, ale jednocześnie, w zmienionych warunkach, stał się jego ofiarą ${ }^{29}$. Siły, które go wyniosły i którymi przewodził ze swoimi absolutnymi ideami, zamkniętymi formami własności i władzy, nie mogły mieć innego wodza, nie mogły korzystać z innych metod. Stalin stał się ofiarą systemu w 1956 roku, kiedy referat Chruszczowa ujawnił ciemne strony stalinowskiego Związku Radzieckiego. Zmieniła się ekipa rządząca, mechanizmy sprawowania władzy pozostały jednakże identyczne, albowiem eliminacja stalinowskiego terroru nie znaczyła zmiany podstawowych cech systemu. Stalin przegrał nie $\mathrm{z}$ tego powodu, że „wypaczył marksizm”, ale właśnie dlatego, że chciał go urzeczywistnićs $^{30}$. Đilas uważa Stalina za prawdziwego rewolucyjnego marksistę, choć kult jednostki i terror przez niego stosowany w najmniejszym stopniu moga wywodzić się z nauki Marksa. Nie zmieniają one jednakże w istocie jego postawy ideologicznej.

W stronę Stalina Đilas wypowiadał również wiele ciepłych uwag. Stwierdzał, że wódz posiadał niezwykłe dary - czujny umysł, zwracał uwage na wszelkie niuanse i dwuznaczności. Potrafił każdą, niesłuszną nawet teorię tak udowodnić, że słuchający nie miał argumentów, aby jej zaprzeczyć. Nie był znakomitym ideologiem, ale jednak zacofaną Rosję przetworzył w imperium i siłę przemysłową, która pretendowała do ogólnoświatowego przywództwa. O ile carska Rosja była rolnicza i prowadziła ekspansję w Azji, to Rosja Stalina stała się przemysłowa, wojskowo-przemysłowa, nastawiona na ekspansję w kierunku kapitalistycznego Zachodu. Jeszcze będąc u władzy, Đilas wielokrotnie wysoko oceniał wojskowe sukcesy Stalina - szczególnie upór w bitwie stalingradzkiej, jak i decyzję o pozostaniu w Moskwie zimą 1941 roku. W tym przypadku poglądy Czarnogórca korespondują z badaczami, którzy demaskują mit wojskowego talentu wodza. Doprowadził on przecież do 20 milionów ofiar w swoim kraju, a obywatele radzieccy walczyli właściwie na dwóch frontach $-\mathrm{z}$ zewnętrznym hitleryzmem i wewnętrznym stalinizmem ${ }^{31}$.

\footnotetext{
M. Đilas, Staljinova senka nad naslednicima, w: Tenże, Pad nove klase..., s. 246.

M. Đilas, Staljin - Lenjinov naslednik, w: Tenże, Pad nove klase..., s. 234.

A. Miercałow, Mit wielkiego stratega, w: Fenomen Stalina, s. 85.
} 
Đilas przestrzegał, że Stalin i stalinizm nie są ostatecznie pogrzebani wszędzie tam, gdzie zarządza partyjna biurokracja, tam gdzie dominują idee budowania społeczeństwa bezklasowego - przy pomocy dyktatorskiej wła$\mathrm{dzy}-$ tam istnieje zagrożenie stalinizmem ${ }^{32}$.

\section{Mao Tse-Tung}

Dla Đilasa przewodniczacy Mao to geniusz wojny partyzanckiej. Do komunizmu nie wprowadził jakiegoś wybitnego wzbogacenia nauki marksizmu, a właściwie doprowadził nawet do jej uproszczenia. Było to jednak dokonane $\mathrm{z}$ taka siłą przekonania, że porównywać to można jedynie z Leni$n^{33}$. Najważniejsze osiaggnięcie Mao - to spojenie doktryny marksistowskiej z rzeczywistością chińską. Jego marksizm nie wykroczył nigdy poza popularyzację, nie przeszedł poziomu szkół partyjnych. Spostrzeżenia Đilasa znajdują potwierdzenie u badaczy zajmujących się chińskim wodzem ${ }^{34}$.

Marksizm wskazywał na rolę miast w rewolucji - Mao dojrzał znaczenie wsi jako podstawy dla chińskiej rewolucji. Mao nie był operatywnym, wybitnym komendantem wojskowym, pisze Đilas. Trwające dwadzieścia lat walki partyzanckie nie wniosły w zasadzie nic do techniki wojennej. Nowością jest koncepcja wojny Mao. W wojnie tej nie decydują regularne wojska, ale aktywność mas - narodu i mobilnych jednostek, takiej walki nie mogą prowadzić generałowie, nawet najbardziej uzdolnieni, tylko wyjątkowi wodzowie polityczni, którzy są w stanie przeniknąć w czas i warunki konfliktu, a następnie utożsamić się z ideałami szeregowych współtowarzyszy broni. Mao zrozumiał „długotrwały charakter chińskiej rewolucji”, niemoc Japonii do okupacji całych Chin. Dlatego najważniejsze dla niego było zachowanie armii i szerzenie powstania, a nie obrona terytoriów i prowadzenie dużych krwawych bitew.

Z tych powodów, dla Đilasa Mao jest w ruchu komunistycznym - najznamienitszym teoretykiem wojny. W historii bitew i rewolucji jako wódz i teoretyk zajmuje według niego jedno z najważniejszych miejsc. Nauki Mao, co najważniejsze, nie były oderwane od lokalnych warunków, i okresu, w którym je szerzył: „Mao nigdy nie przestał być Chińczykiem”"

Teze o Staljinu..., s. 250.

M. Djilas, The Unperfect..., s. 100.

Zob. przykładowo: W. Dziak, J. Bayer, Mao. Zwycięstwa, nadzieje, klęski, Warszawa 2007, s. 266, rozproszone.

35 M. Đilas, Mao, genije gerilske revolucije, w: Tenże, Pad nove klase..., s. 259. 


\section{Tito}

Poglądy Đilasa dotyczące Tity są bardzo wszechstronne i głębokie. Czarnogórzec był w stanie, po 17 latach bliskiej znajomości, bez trudu ująć najważniejsze cechy marszałka. W wyniku swoich analiz i przemyśleń Đilas stwierdzał dość kontrowersyjnie, że bardziej zajmująca jest osoba Tity, niż jego polityczne osiągnięcia. Analizując tok myślenia Đilasa na temat marszałka, zadziwia wyjątkowy brak chęci odegrania się na swoim prześladowcy, który 8 lat trzymał Đilasa w więzieniu. Oceny Czarnogórca dotyczące Tity są bardzo stonowane. Jak wspomina Dobrica Ćosić, Đilas w dyskusjach na temat lidera KPJ zawsze wyszukiwał jego pozytywne strony, przyznawał jego zdolności i zasługi ${ }^{36}$.

Tito, jak pisze Đilas, nie miał żadnych wyjątkowych talentów - oprócz talentu politycznego. Do tego posiadał błyskotliwą inteligencję i silną koncentrację $^{37}$. Słaby mówca, rozwlekły pisarz, ale za to biegły w kwestiach technicznych. Wybitnie odczuwał grożące mu niebezpieczeństwa. Tito w każdym porządku odgrywałby zauważalną, zdecydowaną rolę. Ale tylko poprzez komunizm mógł zostać wodzem rewolucji i absolutnym władcą jakiegoś państwa. Tito - to urodzony buntownik, w ZSRR nauczył się, że instytucje - partia, władza, są ważniejsze od idei. Bardzo mu zależało na określonym, wybitnym miejscu w historii. Miał skłonność identyfikować najważniejsze procesy zachodzące $\mathrm{w}$ kraju $\mathrm{z}$ własną osobą - transformacja rewolucyjna musiała być ściśle związana z jego osobistą władzą. Według Đilasa Tito był świadomy tego, że nie zostawia żadnego spadkobiercy do władzy: miał nawet pewność co do tego, że nikt nie mógłby go zastąpić na stanowisku prezydenta. Tak wysoko oceniał siebie, swoją pracę i dorobek, że był przekonany, iż stworzył wszelkie warunki ku temu, aby nikt nie był w stanie go przewyższyć. Historia pokazuje, że w tym przypadku osiągnął pełen sukces.

Tito od początku orientował się na jugosłowiaństwo. Respektował Serbów, głównie za ich państwowotwórczego i bojowego ducha. Wierzył, że w przyszłości jugosłowiańskie narody połączą się w jeden naród. Ale najważniejsze było dla niego wspólne państwo, a nie etniczne pokrewieństwo. Jako Chorwat z Zagorja był specyficzny dla przeważającej części Jugosłowian. W swojej warstwie obyczajowej dla większości był osobą obcą; pozbywając się swojego nacjonalizmu mógł się stać i stał się zdecydowanie ponadnarodowym władcą. Đilas unika ocen, że Tito robił wiele, aby osłabić znaczenie

D. Ćosić, Piščevi zapisi (1969-1980), Beograd 2001, s. 252-253.

M. Djilas, Tito. The story from inside, New York 1980, s. 7. 
Serbów we wspólnym państwie, oraz że usuwał ich ze stanowisk kierowniczych z powodów narodowościowych. Współczesna historiografia i publicystyka w Serbii znajduje elementy potwierdzające tezę o celowym osłabianiu żywiołu serbskiego, m.in. poprzez faworyzowanie kosowskich Albańczyków czy bośniackich Muzułmanów. Đilas tego nie dostrzegał.

Jest oczywiste, że Josip Broz był zwolennikiem Stalina jeszcze przed przybyciem do Moskwy w 1935 r. Đilas stwierdza, że stalinizm był kompatybilny z mentalnością Tito, z jego rozwojem ideologicznym. Dlatego sam nie miał oporów w przeprowadzeniu czystek wewnątrz swojej partii. Straty jugosłowiańskich komunistów w czystkach były dla niego logiczne i nieuniknione.

Đilas odpowiada również na pytanie: co Tito czerpał z ideologii? Z doświadczenia rewolucji rosyjskiej wynosił, że nowa forma władzy nie może przetrwać bez poparcia nowego rodzaju partii. Taka partia musi być zcentralizowana w ideologii i organizacji. Zasady marksizmu-leninizmu dla Tity pozostały do końca podstawą, niezmienialne, nienaruszalne. Najbliższa mu była ideologia zakładająca nie tylko bolszewicki typ partii, ale i przywódcę (ewentualnie przywództwo), który kieruje ugrupowaniem i zachowuje jego ideologiczną czystość. Ideologia i partia były naczyniami organicznie powiązanymi. Ideologia nie mogła w żadnym momencie zmienić swoich podstaw. Tito wierzył, że partia musi kontynuować swoją walkę w pogoni za monopolistyczną władzą. Wszystkie te procesy winny toczyć się jednocześnie, aby osiągnąć cel przyszłości - utopię, w której nie ma klas, władzy i polityki.

Đilas doskonale znał Titę od strony praktycznego sprawowania władzy i kierowania ideologią partii. Stwierdza, że Tito zasadniczo nie tworzył nowych idei - w Jugosławii wszystko, co było nowe, powstawało w umysłach jego doradców (Kardelja, Dijlasa, Bakarića, Kidriča). Ale wykazywał niezwykłe zdolności w absorpcji tych idei szczególnie, kiedy wydawały się bardzo przydatne we wzmacnianiu jego władzy. Tak było w przypadku wprowadzania reformy samorządowej oraz $\mathrm{w}$ przypadku idei niezaangażowania. Tito pozostał doskonałym organizatorem i propagatorem tych koncepcji ${ }^{38}$. Đilas przyznaje Ticie autorstwo jedynie mało oryginalnego sloganu „jedność i braterstwo" (bratstvo i jedinstvo).

W konfrontacji ze Stalinem Tito zrozumiał, że absolutni władcy trwają tak długo, jak ich władza. Czuł, że jego władza absolutna będzie usprawiedliwiona tak dopóty, dopóki będzie mógł prowadzić Jugosławię, z zacofanego i podzielonego kraju, ku niezależności i prosperity ${ }^{39}$. W kwestii zachowania

38 M. Đilas, Vlast, London 1983, s. 212.

39 Tenże, Tito..., s. 136. 
pełni władzy zawsze pozostawał najbardziej czujny i przewidujący. „W momencie kiedy chcieliśmy ograniczyć władzę partii, Tito po przemyśleniu sprzeciwił się temu - zazdrosny był o swoją osobistą władzę"40.

Po rozprawie z Đilasem (1954 r.) Tito miał świadomość, że zagrożeniem dla niego i jego systemu jest góra partyjna: jeśli góra ta będzie podzielona - takie zagrożenie schodzi na niższy poziom, do pośrednich warstw partyjnych i szeregowych członków. Wiedział jednakże, że reagować trzeba na wszystkie zagrożenia - tak było w przypadku zagrożenia ze strony zwolenników Stalina - „ibeowców”, tak było z B. Neškovićem, M. Đilasem, z chorwackimi nacjonalistami czy serbskimi liberałami (1971-1972). Tito starał się rządzić samodzielnie. Po przejęciu władzy w KPJ (1937 r.) wzywał KC partii tylko wtedy, gdy było mu to niezbędnie potrzebne. Stało się tak w przypadku V Kongresu KPJ, kiedy potrzebował oparcia w walce ze Stalinem. Gdyby nie istniały takie konieczności, wzywanie szerszych ciał partyjnych długo nie byłoby praktykowane.

Đilas - bez żadnych wątpliwości - wskazuje, że decyzję o założeniu obozu na Golim Otoku, gdzie maltretowano przeciwników ekipy titowców, podjął pod koniec 1948 r. sam marszałek, nie konsultując się z innymi liderami partii. $\mathrm{O}$ ile bowiem mógł się spodziewać poparcia w tej kwestii ze strony dołów partyjnych, to grupa najwyższych liderów KPJ nie wykazywała $\mathrm{w}$ tej sprawie silnego przekonania. Đilas podejrzewa, że decyzja ta podyktowana była chęcią jak najszybszego podjęcia kroków zaradczych, aby od razu stłumić i uciszyć prostalinowską opozycję: „Tito był królem, i to mściwym królem" ${ }^{41}$ - nie zamierzał wybaczyć swoim przeciwnikom i raz na zawsze pozbywał się ich z polityki.

Đilas darzył lidera komunistycznej Jugosławii dużym szacunkiem. George Urban stwierdził nawet, że w swojej książce ukazał on Titę jako w pełni oddanego komunistę, wielkiego wizjonera i prawego człowieka, dał „zaskakująco korzystny i pełen czci portret" ${ }^{42}$. Co tłumaczy takie stanowisko? Đilas zastosował zapewne metodę porównawczą, przyglądając się sukcesom różnych liderów komunistycznych. W tym przypadku wódz słabego i zacofanego kraju, podzielonego na wiele narodowości i drążonego przez multum nieporozumień, był w stanie na arenie międzynarodowej zająć miejsce w pierwszym szeregu światowych mężów stanu. O Jugosławię, z różnym natężeniem, zabiegały największe mocarstwa świata.

\footnotetext{
Dżilas o Gorbaczowie, Warszawa 1989, s. 25.

Tamże, s. 38.

Tamże, s. 35.
} 
Tito był politykiem z wyjątkowymi osiągnięciami w ramach ruchu komunistycznego. Niemniej, stwierdza Đilas, jego działalność stanowiła porażkę, jeśli weźmiemy pod uwagę kwestie tego, co demokratyczne i ludzkie ${ }^{43}$. Był tak przywiązany do swojej władzy, że zmiatał wszelkie siły, które mogły wzbogacić życie społeczne, uczynić je bardziej otwartym i bardziej kreatywnym dla człowieka i społeczeństwa, ale tym samym zagrozić jego pełnej władzy. Dlatego titoizm to dla Đilasa jedynie pewien system władzy osobistej, wprowadzenie jednej formy własności, monopolu partyjnej biurokracji i jednopartyjnego systemu. Nie stanowi więc żadnego poważnego wzbogacenia doktryny marksizmu, nie mówiąc już o budowaniu doskonałego społeczeństwa. Zupełnie inny obraz Tity daje socjolog, Todor Kuljić, który stwierdza, że Titę właśnie będzie się pamiętało jako władcę próbującego demokratyzować socjalizm, który zapewnił narodom Jugosławii najdłużej trwające wspólne państwo. Uznaje go także za wybitnego reformatora socjalizmu ${ }^{44}$.

\section{Gorbaczow}

W latach 80. dużo miejsca w swojej publicystyce Đilas poświęca postaci Gorbaczowa. Jego opinie wydają się bardzo celne, przewidywania w pełni trafione.

„Gorbaczow wygląda na prawdziwie wiernego. Jest człowiekiem, który zdał sobie sprawę z tego, na co choruje system, i próbuje zmienić monarchię absolutną na monarchię konstytucyjną" ${ }^{45}$. Đilas stwierdzał, że Gorbaczow to radykał-populista. Jego taktyką jest ostrożna destalinizacja; każdego dnia on i prasa $\mathrm{w}$ pełni go popierająca posuwają się ku pełnemu rozliczeniu stalinizmu. Uważał, że nie jest pięknie zarzucać Gorbaczowowi, wiary w „dobrego Lenina" i nawet w ideologię. Niemniej stalinizm to przecież zwycięski prąd leninizmu, a Gorbaczow wydaje się nie zdawać z tego sprawy. Nie ma dobrego Lenina i złego Stalina, choć nie są oni jednakowi ani jako osoby, ani w swoich dziełach: Lenin to dyktatura partii rewolucyjnej, Stalin to tyrania zbiurokratyzowanej, rewolucyjnej partii ${ }^{46}$. Nie ma jednak powrotu do czystego leninizmu poprzez krytykę stalinizmu, są to rzeczy nieoddzielne. W tym sensie, dżilasowa ocena Gorbaczowa sprowadzała się do wniosku, że atakuje on stalinizm z lewej strony, z kolei M. Rakowski konstatuje, że pierwszy sekretarz KPZR płynął bardziej środkiem rzeki, nie podchodząc ani do jednego, ani do drugiego brzegu ${ }^{47}$.

M. Djilas, Tito..., s. 179.

44 T. Kulijć, Tito. Socijološko-istorijska studija, Zrenjanin 2005, s. 494, 512.

Dżilas o Gorbaczowie..., s. 27.

${ }^{46}$ M. Đilas, Dvorsko-partijski puč iz kremlja, w: Tenże, Pad nove klase..., s. 293.

47 M. F. Rakowski, Gorbaczow. Pierwszy i ostatni, Warszawa 1992, s. 124. 
Gorbaczow był dla Đilasa bez wątpienia silnym, uzdolnionym politykiem („autorytarna osobowość”), choć nie bez słabości, które mogły być zgubne dla niego i dla powodzenia jego reform: „teoretyczny horyzont Gorbaczowa jest już przestarzały: to jest prawdopodobnie powodem, że opierał się na własnej władzy, a nie na instytucjach. Do uprawomocnienia swojej władzy doszedł poprzez ustępstwa wobec partyjnej biurokracji, która skorzystałaby z każdej dogodnej okazji, by go później zdradzić" ${ }^{48}$. Dlatego jego wiara w to, że przekształcona, zreformowana KPZR mogłaby zbudować socjalizm „z ludzką twarzą", była naiwna.

Przed upadkiem ZSRR Đilas spekulował czy Gorbaczow będzie w stanie zreformować system. O ile wszystkie komunistyczne państwa wchodzą w dramatyczny okres, to przykład ZSRR jest specyficzny, a jego system kluczowy - powstał z rewolucji i w swych zasadach nie zmienił się znacząco od 1917 r. Wielonarodowe imperium jest ponadto jeszcze bardziej zcentralizowane niż pod carami. „Rewolucja od góry”, zapowiadana przez Gorbaczowa, przynosiła początkowo nieznaczne zmiany, ale walka z nomenklaturą partyjną wydawała się od początku przegrana. Do zmian potrzeba było jednakże prawdziwej rewolucji.

Đilas zadaje pytanie: czy można zreformować system sowiecki? W poszukiwaniu odpowiedzi stwierdzał, że w rzeczywistości nie jest to możliwe: totalitarnego systemu - w imperium - nie można zreformować, tylko dlatego, że jest on właśnie totalitarny, zamknięty w sobie, samowystarczający w swojej formie i strukturze. Taki system przekształca się w procesie butwienia i gnicia, i wówczas musi znaleźć się siła, która go w końcu wyeliminuje $e^{49}$.

Đilas nie wierzył, że Gorbaczow jest $w$ stanie zreformować ZSRR, $i$ to nie z powodów jego poglądów i światopoglądu, ale dlatego, że system ten można jedynie zniszczyć i zastąpić innym. W 1991 roku Đilas bez wahania stwierdzał, że okres Gorbaczowa skończył się wraz z puczem, wraz ze zwycięstwem narodu, narodu-armii na czele z Jelcynem, bez względu na to, jaką rolę w przyszłości Gorbaczow będzie chciał odegrać.

Jakie są więc, według Đilasa, zasługi Gorbaczowa? Przede wszystkim zniszczył stalinizm, stalinistyczny system ideologicznego i innych terrorów. Gorbaczow nie chciał podważać leninizmu. Ale stalinizm to leninizm, który doszedł do swojego najdalszego stadium. Gorbaczow więc, sam tego nie chcąc, zakwestionował także leninizm. I zrobił to ze wszystkimi konsekwen-

Dżilas o Gorbaczowie..., s. 27.

49 M. Đilas, Dvorsko-partijski puč..., s. 292. 
cjami. Można by to podsumować bardziej poetycznie: Gorbaczow wypuścił dżina z butelki, do której ten już nie chce wrócićs ${ }^{50}$.

\section{Zakończenie}

Milovan Đilas ustrój komunistyczny znał od podszewki, w swoim czasie tworzył partię komunistyczną i demokrację ludową. W wodzach rewolucji dostrzegał rzeczy, jakie trudno jest dostrzec tym, którzy nigdy nie byli w partii komunistycznej. Wspólnym mianownikiem dla wszystkich bohaterów jego analiz jest fakt, że system, który próbowali budować, był w rzeczywistości nieosiągalny. Jako marksiści wszyscy chwytali się różnych działań, aby osiągnąć swój cel, i wszyscy od początku byli skazani na porażkę. Đilas nie bez zdziwienia zauważał, że zdecydowana większość komunistycznych wodzów była megalomanami. Nie wyznaczali oni swoich następców, ale nie dlatego że nie mogli ich znaleźć, ani nie dlatego, że uważali się za niezastąpionych: zwyczajnie nie pragnęli $\mathrm{w}$ żadnym momencie być zastąpionymi, wierząc w swoje nieskończone trwanie razem z niezniszczalną, nieprzemijającą partią. Na ołtarzu osiągnięcia „wielkiego celu” i zajęcia należnego miejsca w historii nigdy nie wybierali środków - moralność postępowania i zachowania leżała w obszarach drugorzędnych priorytetów. W imię abstrakcyjnego szczęścia przyszłych pokoleń wszystko jest przecież dozwolone i moralne $e^{51}$.

Czy sam Milovan Đilas, w latach pełnienia odpowiedzialnych funkcji w KPJ, odbiega od wizerunków komunistycznych wodzów? Było w nim wiele charyzmy, uporu i odwagi. Przez lata wierzył w budowę doskonałego społeczeństwa na zasadach marksizmu-leninizmu, później w możliwość reformy ustroju, by socjalizm ponownie uzyskał swój blask. Po opuszczeniu szeregów partii i unaocznieniu sobie oporu partyjnej biurokracji przed jakimikolwiek zmianami, wszelkie próby odżywienia systemu uznał za niemożliwe. Rozejściu z marksizmem „pomagały” lata więzienia, kiedy odczuwał na sobie totalitarny but komunistycznej władzy, która za nieopatrzne „korzystanie” z wolności słowa natychmiast kierowała niepokornych do zakładów karnych. 


\section{Abstract}

In this paper, the author presents some of Milovan Đilas' views on the five most important leaders of the left, namely Marx, Lenin, Stalin, Tito and Gorbachev. Đilas had a very thorough knowledge concerning them, mainly due to his long affiliation with Communism. He ranked among the most prominent communist politicians in Yugoslawia, where, together with Tito and Kardelj, he established a people's democratic system. His views, as presented in the article, were formed in the 1960s, when he finally separated himself from Marxism.

For Đilas, Marx was a prophet, writer and scientist, Lenin the founder of atotalitarian state, and Stalin his most outstanding follower. He also held very interesting views on Tito. He perceived him mostly as a politician, whose concern was to keep the hold of power in all of its forms. Despite having spent 8 years in prison because of Tito's hatred toward him, Đilas frequently spoke in favour of the marshal.

Đilas believed Gorbachev only wanted to dismantle Stalinism, and not Leninism. Yet for Đilas there was no difference between these two systems, and destroying Stalinism meant destroying Leninism.

He saw in communist leaders megalomaniacs, convinced of their indispensability, and confident they would last forever along with the communist party. Most of them were capable of putting aside morality and honesty in the name of abstract happiness. 